MARIUSZ SZTABA

Katolicki Uniwersytet Lubelski Jana Pawła II

Lublin

\title{
PEDAGOGIA OSOBY \\ WOBEC ZAGADNIENIA DUCHOWOŚCI
}

Streszczenie: Nie można mówić o realistycznej pedagogii osoby bez uwzględnienia jej duchowości i wychowania religijnego będącego prostą jej konsekwencją. W artykule prezentowana jest problematyka duchowości osoby na podstawie analiz realistycznej filozofii bytu, wzbogaconej krytycznie przyjętą filozofią świadomości. Przy omawianiu zagadnienia duchowości osoby wskazuje się także na jej liczne zagrożenia oraz pedagogiczne implikacje.

Słowa kluczowe: osoba, dusza, duchowość, transcendencja, wychowanie religijne

\section{Wstęp}

Zagadnienie relacji pomiędzy pedagogiką a duchowością nie jest nowe. Zanim powstała naukowa pedagogika, a ten fakt łączymy z Janem Fryderykiem Herbartem (1776-1841), namysł pedagogiczny nad wychowaniem i kształceniem związany był organicznie z filozofią (o. Jacek Woroniecki, idąc za myślą św. Tomasza z Akwinu, uważał pedagogikę za etykę wychowawczą), a później z teologią (wiedza pedagogiczna była włączana do teologii moralnej szczegółowej). Fakt ten rzutował m.in. na to, że teoria i praktyka pedagogiczna były wrażliwe na duchowość człowieka, tzn. na to, co oryginalne w jego człowieczeństwie. Nie oznacza to jednak, że każda pedagogika (nurt, system, kierunek) liczy się z duchowym wymiarem człowieka albo adekwatnie rozumie i interpretuje ten wymiar (Sztaba 2013). Rzecz podobnie ma się z pedagogiami ujmowanymi jako zespół metod i środków wychowania oraz kształcenia, stosowanych przez wychowawcę/nauczyciela, a więc z praktyczną sztuką wychowania i kształcenia (Hejnicka-Bezwińska 2008).

Podejmując problematykę duchowości w kontekście pedagogii osoby, muszę na początku prowadzonych analiz zaznaczyć, że każde z kluczowych pojęć zawartych w tytule („pedagogia”, „osoba”, „duchowość”) domaga się osobnej analizy i prezentacji. W artykule jednak uwagę skupię na rozumieniu i znaczeniu duchowości, 
odwołując się do analiz Polskiej Szkoły Filozofii Klasycznej ${ }^{1}$. Szkoła ta, mając świadomość różnorakich ujęć osoby (różnych personalizmów) ${ }^{2}$, w swoich badaniach dąży do przedstawienia integralnej wizji człowieka w ramach personalizmu uwzględniającego to wszystko, co konstytuuje człowieka jako osobę, unikając dzięki temu pułapki redukcjonizmu i dualizmu - o czym będzie mowa w dalszej części analiz ${ }^{3}$. W pierwszej kolejności zwrócę uwagę na sytuację duchowości osoby dziś. Następnie zaprezentuję wieloznaczność terminu „duchowość” i jemu pokrewnych. W dalszej kolejności poddam analizie drogi poznania duchowości osoby oraz wskażę na duszę jako jej źródło. Po tych analizach zaprezentuję metafizyczne rozumienie transcendencji, będącej czytelnym znakiem duchowości człowieka. Następnie wskażę na duchowość religijną jako szczególny typ duchowości osoby otwierający ją na Absolut. Całość analiz dopełnię postulatami wobec pedagogii osoby, zwracając uwagę na dynamizm i potencjalność ludzkiej duchowości.

\section{Paradoksalny renesans duchowości i przejawy zapotrzebowania na nią}

Z jednej strony, pod wpływem fascynacji naukami przyrodniczymi i scjentyzmu, materializmu oraz różnego rodzaju ideologii ${ }^{4}$, a także sekularyzacji i ateizmu, doszło do zanegowania duchowego wymiaru człowieka (Składanowski 2013; Sztaba

${ }^{1}$ Polska Szkoła Filozofii Klasycznej gromadzi naukowców uprawiających filozofię na KUL-u oraz będących w orbicie oddziaływania lubelskiej filozofii klasycznej, charakteryzującej się realizmem ontycznym i intelektualizmem poznawczym bazującym na empirii. Do głównych twórców szkoły, której rozwój można podzielić na trzy okresy, należą: Jerzy Kalinowski, Stanisław Kamiński, Mieczysław Albert Krąpiec, Marian Kurdziałek, Stefan Swieżawski, Karol Wojtyła. Szkoła skupia zarówno zwolenników tomizmu egzystencjalnego, jak i pewne postaci fenomenologii i filozofii analitycznej. Z historią szkoły, jej uczniami i głównymi ideami zapoznają nas publikacje Stanisława Janeczka (Janeczek 2001) i Marii Małgorzaty Boużyk (Boużyk 2013).

${ }^{2}$ Obok metafizyczno-teologicznej koncepcji osoby wskazującej na człowieka jako substancję pierwszą oraz byt rozumny, obdarzony godnością w myśli nowożytnej, a także współczesnej, pojawiają się różnorakie koncepcje osoby zdominowane przez odnoszenie jej do świadomości i samoświadomości (Ch. Wolf, I. Kant, G.W.F. Hegel, Kartezjusz) oraz świata wartości (N. Hartman). Nie wszystkie więc personalizmy adekwatnie rozwiązują problem integralnej wizji człowieka (Jaroszyński 2007).

3 „Bez przyjęcia teorii formy i materii, aktu i możności spiętej istnieniem jako aktem nadrzędnym, nie da się zbudować personalistycznej i integralnej koncepcji człowieka. Dlatego większość współczesnych odmian personalizmu, wywodzących się najczęściej z kantyzmu lub heglizmu, prowadzi w konsekwencji do jakiejś formy spirytualizmu, a nawet do panteizmu. I nawet jeśli mówi się tam o osobie, to nie jest to rzeczywista osoba ludzka" (Jaroszyński 2007, s. 489).

${ }^{4}$ Nie ma miejsca dla duchowości osoby ludzkiej w marksizmie i neomarksizmie oraz neoliberalizmie, dążącym do urynkowienia edukacji i kreowania konsumerycznej tożsamości według rynków, koniunktur i mód; w postmodernizmie, który kreuje antysubstancjalistyczny i antyontologiczny obraz człowieka rozumianego jako „sieć przekonań i pragnień” (R. Rorty), negując duchowy wymiar osoby ludzkiej na rzecz promowania żywiołowej witalności i seksualności (Sztaba 2013). 
2014a). Współczesny materializm, zarówno teoretyczny, jak i praktyczny, wraz z dynamicznym rozwojem technicznym i gospodarczym nie sprzyja postępowi moralnemu i duchowemu ludzkości. Dlatego kardynał Joseph Ratzinger mówił w tym kontekście o „ślepocie duchowej”, będącej skutkiem „zmaterializowania” człowieka, tj. odrzucenia duchowego pierwiastka w człowieku (Składanowski 2013) ${ }^{5}$. Ta „ślepota” stała się też udziałem wielu współczesnych kierunków pedagogiki'.

$\mathrm{Z}$ drugiej jednak strony, wbrew tym tendencjom socjologowie religii dostrzegli na przełomie XX i XXI wieku trend polegający na powtórnym uduchowieniu (respirytualizacji), odkrywaniu transcendencji oraz dowartościowywaniu religii, co stanowi zarazem falsyfikację teorii sekularyzacji, która uważała ów proces za jednokierunkowy i nieodwracalny. Z sekularyzacji zaczęła wyrastać różnej jakości duchowość ${ }^{7}$.

Co więcej, coraz częściej różne dyscypliny naukowe interesują się duchowością jako podstawową wartością i obszarem wspierania osoby w celu jej integralnego rozwoju. Na ten fakt wskazywali już w swoich teoriach warstwicowego rozwoju osoby Wilhelm Flitner, Sergiusz Hessen i Stefan Kunowski (Kostkiewicz 2003), a teraz czynią to badacze i kontynuatorzy ich myśli (Karczewska 2012; Kostkiewicz 2004; Nowak, Ożóg, Rynio 2003). Wspomniani pedagodzy zajmowali się warstwą duchową procesu wychowania, postrzegając człowieka w pełnym bio-psychiczno-duchowym wymiarze ${ }^{8}$. Byli przekonani, że od rozwoju tej warstwy zależy, w jakim kierunku potoczy się historia ludzkości (Kostkiewicz 2004).

${ }^{5} \mathrm{O}$ „duchowym otępieniu” oraz kryzysie duchowym jako źródle wszelkiego rodzaju kryzysu pisali także Danah Zohar i Ian Marshall (2001).

${ }^{6}$ Rozwój pedagogiki naukowej i poszukiwanie przez nią własnej tożsamości oraz autonomii sprawiły, że często gubiono w badaniach pedagogicznych problematykę duchowości człowieka. Nie było na nią już miejsca w pedagogice eksperymentalnej, rozumianej jako nauka przyrodnicza, ani też w ściśle psychologicznych i socjologicznych podejściach do zagadnienia wychowania. Duchowość osoby ludzkiej nie mieści się również w zideologizowanych pedagogikach (Sztaba 2013). Bogusław Śliwerski pisze o tzw. nurcie pedagogiki nietranscendentnej, który w modernizmie zapoczątkował dyskurs emancypacyjny, a obecnie jest rozwijany w postmodernizmie pod postacią teorii krytycznych i radykalnych (Śliwerski 2011). Znamienny jest fakt, że we współczesnych leksykonach i encyklopediach pedagogicznych brakuje pojęcia duchowości. I chociaż, jak przypomina Bogusław Śliwerski, wychowanie to także formacja duchowa, to zagadnienie to analizują tylko pedagogika personalistyczna oraz tzw. pedagogika transcendentna (Śliwerski 2012).

7 Według ks. Janusza Mariańskiego wzrost ponownego zainteresowania duchowością przejawia się i dokonuje w trzech kierunkach. Są to: a) rozwój nowych ruchów kościelnych i zainteresowanie pogłębianiem chrześcijaństwa (tzw. wiosna Kościoła); b) rozwój różnorodnych pozakościelnych form religijności (religion unchurched) w ramach pogłębiającej się alternatywy: wiara chrześcijańska - różne wiary, religie i światopoglądy (duchowość i jej różne formy rozumie się jako jeden z elementów światowego supermarketu i hiperkonsumpcji); c) wzrost fanatyzmu, tj. fałszywej religijności (Mariański 2009; Sztaba 2014a).

${ }^{8}$ U Wilhelma Flitnera rozwój warstwy duchowej był rozumiany jako duchowy proces powstawania w wychowanku moralno-religijnego życia, przez co jawił się on jako istota i cel wychowania. 
Współcześni amerykańscy psychologowie podkreślają, że duchowość „oznacza kontakt z pewną szerszą, głębszą i bogatszą całością, umożliwiającą spojrzenie z nowej perspektywy na naszą ograniczoną sytuację. Duchowość pozwala poczuć, że jest «coś poza» lub «coś jeszcze», co ukazuje inny sens i wartość naszego obecnego położenia” (Zohar, Marshall 2001, s. 29).

W naukach społecznych (szczególnie gdy poszukują one warunków zrównoważonego rozwoju) i medycznych (w obrębie promocji zdrowia i opieki paliatywnej) zaznacza się wyraźny prąd poznawczy, poszukujący w duchowości człowieka zasobów osobowych jednostki oraz tych, które stanowią ważny wymiar kapitału społecznego ${ }^{9}$. W 1995 roku WHO włączyła do kwestionariusza WHOQOL - przeznaczonego do oceny jakości życia w aspekcie zdrowia - pytanie odnoszące się do duchowości, religii i osobistej wiary. Aspekt duchowy rozumie się tutaj jako wewnętrzne zasoby człowieka, zwłaszcza jego ostateczną troskę (ultimate concern). Od tej pory duchowość rozumiana jako kategoria zasobów osobowych jednostki stała się pełnoprawnym przedmiotem badań i dyskusji naukowej. W 2002 roku WHO włączyła zagadnienie duchowości do definicji zdrowia i choroby, wskazując na pilną potrzebę uwzględniania szeroko ujmowanej opieki duchowej, odpowiadającej na coraz lepiej zdiagnozowane indywidualne potrzeby duchowo-religijne osoby (Surzykiewicz 2015).

Prowadzone na Zachodzie badania wskazują także na wyraźny wpływ głębszego doświadczenia duchowego na wybór zawodu i jakość życia zawodowego. W ich świetle dojrzała duchowość związana jest z wyższym poziomem: a) zaangażowania organizacyjnego; b) wewnętrznego zadowolenia z pracy; c) własnego udziału w pracy; d) organizacji opartej na samoocenie; e) wykorzystywania zasad religijnych i duchowych w codziennej pracy, co sprzyja tworzeniu „duchowości miejsca pracy" (Surzykiewicz 2015).

Odkrywane na nowo duchowość i religijność postrzegane są również jako ważny aspekt i podstawa strukturalna kapitału społecznego służącego integracji społecznej. Duchowość, szczególnie religijna, pozwala tworzyć sieci społeczne, które są głównym strukturalnym aspektem kapitału społecznego oraz generatorem zaufania społecznego, korespondującego z udziałem społecznym (Surzykiewicz 2015).

U Sergiusza Hessena związany był z wychowaniem moralnym rozumianym jako wyzwolenie człowieka (zbawienie) i włączenie ukształtowanej osobowości do „wspólnoty duchów”. Stefan Kunowski rozwinął i dopełnił teorię warstwicową, nie ograniczając warstwy duchowej tylko do świata kultury, ale otwierając ją na Boga. Wskazywał więc na piątą warstwę, czysto duchową, którą stanowią życie religijne i głębsze przeżycia światopoglądowe. Według niego warstwa duchowa wieńczy proces rozwoju wychowawczego, będąc etapem docelowym, pozwalającym osiągnąć pełnię człowieczeństwa (Kostkiewicz 2003).

9 Zagadnienie to analizuje i prezentuje w oparciu o najnowszą literaturę niemieckojęzyczną i anglojęzyczną Janusz Surzykiewicz (2015). 


\section{Wieloznaczność pojęcia duchowości i obszary jej badań}

„Duchowość”, „życie duchowe”, „religia” oraz „religijność” to pojęcia wielowymiarowe, kryjące w sobie szereg warstw znaczeniowych i często niesłusznie traktowane jako synonimy. Religia związana jest ze światopoglądem i wspólnie przeżywaną wiarą, którą wierni zachowują w postaci doktryny oraz praktykują w codziennych i świątecznych rytuałach. Jeśli ma zinstytucjonalizowany, społeczny charakter, to u podstaw religijności i duchowości znajduje się indywidualne doświadczenie, które w pewnym stopniu także podlega rytualizacji i przyporządkowaniu określonej wspólnocie potrzeb i idei (Surzykiewicz 2015).

W obliczu stałego poszerzania zakresu znaczeniowego duchowości należy dokonać podstawowego podziału na duchowość pozareligijną, zwaną często naturalną, i duchowość religijną. Pierwsza, zwana przeze mnie także ogólnoludzką, związana jest $\mathrm{z}$ differentia specifica każdego człowieka, opisywaną przez filozofię, psychologię, medycynę, kulturoznawstwo, pedagogikę itd. Druga zaś, bazując organicznie na pierwszej, związana jest z konkretną religią i wyznaniem. Tak więc duchowość nie musi być tożsama z religią i religijnością (Surzykiewicz 2015).

Duchowość naturalna (pozareligijna) stała się dziś pojęciem niezwykle modnym, zawierającym w sobie konotacje autentyczności i osobistej szczerości, wewnętrznej wolności, zgodności ze sobą, innymi i z przyrodą. Jawi się jako przestrzeń wolności w życiu człowieka, umożliwiająca szukanie odpowiedzi na egzystencjalnie ważne pytania i twórczą reorientację, otwarcie na transcendencję i tajemnicę (Surzykiewicz 2015).

Pojęcie duchowości dzięki niedookreślonemu zakresowi i treści jawi się dzisiaj jako nadrzędne, ale zarazem podatne na różnorakie manipulacje i zafałszowania. Wieloznaczność i niejasność terminu „duchowość” prowadzi często do upraszczających uogólnień i niebezpiecznych dwuznaczności. Bardzo wyraźnie widać ten fakt w tzw. ponowoczesności ${ }^{10}$. Tworzeniu się „nowej duchowości” - całkowicie zindywidualizowanej, pozainstytucjonalnej i bezwyznaniowej, zwanej przez Thomasa Luckmanna „niewidzialną religią” - sprzyjał zaistniały w latach siedemdziesiątych XX wieku ruch New Age ze swoistą astralną „metafizyką” oraz ideologia postmodernizmu, która fetyszyzuje pluralizm, różnienie się, tymczasowość i płynność (Kowalczyk 2004) ${ }^{11}$. Do charakterystycznych cech „nowej duchowości” zalicza się: a) rezygnację $\mathrm{z}$ wiary $\mathrm{w}$ pojmowanego antropomorficznie i osobowo

${ }^{10}$ Ponowoczesność to kategoria szersza od postmodernizmu - oznacza całą formację historyczną, która zgodnie z nazwą nadeszła po erze nowoczesnej i trwa (Kuźniarz 2011).

${ }^{11} \mathrm{~W}$ ponowoczesności ludzie w odniesieniu do transcendencji (o ile ma rację bytu) podobni są do „duchowych wędrowców”, którzy nie mają jak pielgrzymi jasno określonego celu, a rozwój swojej duchowości uznają za własne, indywidualne i autonomiczne zadanie (Marszałek 2013a). 
transcendentnego Boga na rzecz tzw. sacrum ${ }^{12}$; b) uchylenie kartezjańskiego dualizmu materii i ducha, by zastąpić go koncepcjami panteistycznymi i panteizującymi; c) obecność okultyzmu, magii, spirytyzmu, teozofii, wróżbitów ${ }^{13}$; d) zainteresowanie odmiennymi stanami świadomości, zjawiskami okołośmiertnymi oraz typu extra body experience (bycie poza ciałem), tworzącymi rodzaj prywatnych kultów; e) negację tradycyjnie pojmowanej idei postępu technicznego oraz powrót do natury i nastawienia antycywilizacyjnego (Pawluczuk 2004); f) samorealizację, autokreację; g) sakralizację praktyk psychoterapii, działań artystycznych, politycznych, a nawet ekonomicznych (Marszałek 2013a).

W związku z zasygnalizowaną sytuacją zasadne wydaje się rozpatrywanie duchowości z perspektywy różnych dyscyplin naukowych, gdyż pojęcie duchowości (życia duchowego) poprzez swoje bogactwo znaczeniowe i różnorodne użycia nabiera charakteru interdyscyplinarnego ${ }^{14}$. Takie podejście badawcze pozwala wydobyć różne wymiary, aspekty i znaczenia duchowości (antropologiczny, religijny, kulturowy, filozoficzny, psychologiczny, socjologiczny), przywołując podstawowe i zarazem komplementarne sensy tego pojęcia ${ }^{15}$.

W tym momencie, nie omawiając wspomnianych wymiarów, zaznaczę tylko, że duchowość w sensie podstawowym jest kategorią antropologiczną, wskazującą na jedną ze specyficznych właściwości natury ludzkiej, tzn. na doświadczenie transcendencji osoby. Dzięki temu duchowość nie jest jakąś abstrakcją, ale ma swój kształt oglądowy, bowiem duchowość osoby poznajemy poprzez jej transcendencję. Jest otwarta dla oglądu, ale także dla wglądu. Wszystkim przejawom duchowości osoby musi odpowiadać realna immanencja ducha - dusza, o czym zapomina się

12 W świetle badań socjologicznych i fenomenologicznych świętość związana jest z sacrum rozumianym jako przeciwieństwo profanum i stanowi fundamentalną cechę każdej religii, bardziej dla niej istotną niż wyobrażenie boskości. „Święte” odnosi się do tego co absolutne i identyfikowane z boskością. To swoista jakość aksjologiczna wypływająca z boskości i skierowana ku człowiekowi. To także pożyteczna poznawczo kategoria, która umożliwia uniwersalne badanie fenomenu religijnego w każdej z jego treściowych postaci. Takie jednak ujęcie sacrum charakteryzuje się medialną otwartością i niedookreśleniem zarówno co do treści, jak i zakresu. Dlatego dzisiaj podkreśla się konieczność sięgania do metafizycznych podstaw w badaniu sacrum. W świetle badań interdyscyplinarnych i wkładu filozofii realistycznej oraz teologii o orientacji katolickiej wydaje się być słuszne twierdzenie, że nie można zbyt łatwo utożsamiać sacrum ze świętością (Kunicki 2006; Zdybicka 2007).

13 W Polsce wróżbita to zawód ujęty w klasyfikacji zawodów i specjalności regulowanej Rozporzadzeniem Ministra Pracy i Polityki Społecznej z 27 kwietnia 2010 r. w sprawie klasyfikacji zawodów i specjalności na potrzeby rynku pracy oraz zakresu jej stosowania, który posiada kod 516102.

14 Interesujących i nawiązujących do najnowszej literatury przedmiotu przemyśleń dotyczących tych zjawisk dostarcza pierwszy rozdział monografii Lidii Marszałek (Marszałek 2013a).

15 Zagadnienie to analizuję i prezentuję w osobnym artykule, dotyczącym rozumienia życia duchowego w kontekście filozofii i pedagogiki kultury Bogdana Nawroczyńskiego (Sztaba 2015). 
w dzisiejszej dyskusji na temat duchowości człowieka. To ona decyduje o duchowości osoby, będąc faktem ogólnoludzkim (Marek 2015; Marszałek 2013a).

Stefan Kunowski, mówiąc o duchowości jako właściwości ogólnoludzkiej, wskazywał na jej charakterystyczne cechy: a) jest rozumna, tzn. zdolna do obiektywizacji poznania rzeczywistości w procesie abstrakcji umysłowej; b) jest zdolna do wartościowania i oceniania wszystkich przedmiotów i przeżyć, przez co może dążyć do najwyższych ideałów - prawdy, dobra, piękna oraz świętości - i żyć nimi; c) jest wolna w wyborze dobra i posiada możność brania odpowiedzialności za czyny osoby; d) jest twórcza, ale nie stwórcza ${ }^{16}$; e) jest otwarta na głębię metafizyczną, przekraczając granice zmysłowego doświadczenia (transcendencja) i sięgając aż do źródeł każdego bytu - do absolutu/Boga (Kunowski 2001).

Ten podstawowy, antropologiczny aspekt duchowości rozwija w swoich analizach Paweł Socha, wskazując na następujące sfery duchowego życia człowieka: a) świadomość i samoświadomość; b) rozum i mądrość; c) uczucia; d) wrażliwość (racjonalną, emocjonalną, percepcyjną); e) twórczość - zdolność do transgresji i wyobrażeń; f) poczucie estetyczne; g) moralność; h) religijność; i) światopogląd; j) wiarę (Socha 2000) ${ }^{17}$.

Reasumując powyższe analizy, można stwierdzić, że życie duchowe jawi się jako pochodna duchowości, a ta z kolei - jako wynik istnienia i działania duszy ludzkiej. Dopiero na bazie tej ogólnoludzkiej właściwości buduje się i rozwija duchowość religijna (Marszałek 2013a; Werbiński 1993).

16 Obecnie mamy problem z odróżnianiem twór c zości od stwór c zości (k reowa n i a). Dlatego bezmyślnie i w sposób nieuprawniony posługujemy się czasownikiem „kreować". Mocno akcentował to św. Jan Paweł II w Liście do artystów, wskazując na zasadniczą różnicę pomiędzy Stwórcą, który wydobywa coś z nicości (ex nihilo sui et subiecti), a twórcą, który „wykorzystuje coś, co już istnieje i czemu on nadaje formę i znaczenie” (nr 1). W tym samym duchu wypowiadał się Benedykt XVI, który jeszcze jako kardynał obnażał „stwórcze” zapędy człowieka określane jako kreatywność. Podkreślał wówczas, że termin ten powstał na gruncie światopoglądu marksistowskiego i związany był z przekonaniem, że „w świecie, który sam w sobie jest bezsensowny i powstał w wyniku ślepej ewolucji, człowiek w sposób twórczy buduje sobie nowy, lepszy świat. W nowoczesnych teoriach sztuki chodzi tutaj o nihilistyczną formę twórczości: sztuka nie ma niczego naśladować, a twórczość artystyczna jest wolnym działaniem człowieka, które nie przywiązuje się do żadnych miar i celów, i które nie podlega jakimkolwiek pytaniom o sens. Dające się słyszeć w takich wizjach wołanie o wolność staje się w stechnicyzowanym świecie wołaniem o pomoc. Sztuka pojmowana w ten sposób wydaje się bowiem ostatnim miejscem, które mogłoby się stać schronieniem dla wolności. Prawdą jest, iż sztuka ma związek z wolnością. Jednakże tak rozumiana wolność jest pusta. Nie zbawia, lecz sprawia, że ostatnim słowem ludzkiej egzystencji zdaje się być rozpacz" (Ratzinger 2002, s. 151).

17 Paweł Socha wnikliwie opisuje elementy duchowości człowieka, ukazując między nimi różnice, ale i komplementarność. Ponieważ analizuje czynniki osobowościowe duchowości, wydaje się, że łączy nieraz elementy życia psychicznego i duchowego człowieka. Dla naukowego ich rozróżnienia tak prowadzona analiza może stanowić problem, ale dla adekwatnej antropologii jest ona wyrazem integralnego ujmowania i analizowania bycia oraz działania osoby jako bytu cielesno-psychiczno-duchowego (Kostkiewicz 2004; Marszałek 2013; Socha 2000 ). 


\section{Integralna i adekwatna antropologia źródłem odkrycia i analizy duchowości osoby}

Wielu badaczy twierdzi, że duchowość ogólnoludzka jest ze swojej natury bezpośrednio nieuchwytna i nie poddaje się ścisłemu definiowaniu. Takie podejście sprzyja rozprzestrzenianiu się mistycznie tajemniczej i ulotnej duchowości. Jeśli do tego stanu rzeczy dodamy tzw. błąd antropologiczny ${ }^{18}$, to mamy do czynienia z różnymi deformacjami duchowości naturalnej, a pośrednio także duchowości religijnej. Rozumienie duchowości zależy bowiem od rozumienia człowieka - antropologii (Krąpiec 2007; Sztaba 2014b). W historii filozofii najczęstszą odpowiedzią na pytanie o to, kim jest człowiek, był redukcjonizm lub dualizm (Jaroszyński 2007).

Redukcjonizm sprowadza człowieka albo do materii, albo do ducha, skutkując antropologią naturalistyczną/materialistyczną bądź spirytualizmem. Pierwsza koncepcja charakteryzuje się redukcją ducha i duchowości do materii (Składanowski 2013). Nowy naturalizm sprowadza osobę i jej życie, w tym duchowe, do fizyki, chemii, neurofizjologii itd. Dlatego zamiast takich terminów jak: „umysł”, „świadomość”, „percepcja”, „myśl” pojawiają się nowe: „synapsa”, „lobotomia”, „proteina”, „sygnały elektryczne” (Possenti 2007). Z kolei spirytualizm (bogata i różnorodna filozofia ducha) uwypukla ducha jako realną samoświadomość, charakteryzującą się refleksyjnością, twórczością, wolnością i partycypacją (Chudy 2007).

Współczesny redukcjonizm dotyczy także relacji dusza - umysł - ciało. Pod wpływem filozofii umysłu oraz „nauk o umyśle” zastępuje się termin „dusza” pojęciem umysłu (ang. mind), będącym pewnym pars pro toto. Wobec marginalizacji i zapominaniu o duszy współczesne badania nad człowiekiem koncentrują się na umyśle i relacji umysł - ciało, o czym świadczy bogata literatura na temat mind-body problem. Jednak autentyczny problem polega na tym, że nie można utożsamiać duszy z umysłem, jak zrobił to Kartezjusz i czynią jego następcy. Vittorio Possenti zauważa, że pytanie o duszę zdecydowanie wyrasta ponad kwestię umysłu i mózgu. „Umysł jest źródłem aktów poznawczych, ale nie jest źródłem życia, tak jak dusza. Jest aktywnością poznawczą duszy, nie jest więc tym samym co dusza. Umysł ludzki istnieje jako esse in anima, jest więc iluzją utrzymywać, że pozostając przy relacji umysł - ciało, możliwe będzie odpowiednie wyjaśnienie problemu duszy" (Possenti 2007, s. 113-114). Dlatego Possenti podkreśla, że zawsze trzeba pytać się, co jest podmiotem umysłu i ciała oraz co zapewnia jedność właściwą bytowi ludzkiemu.

Dualizm wskazuje natomiast na dwa komponenty człowieka: materię i duszę, jako niezależne od siebie, przez co nie jest on jednym bytem. Dualizm antropologiczny sprawia, że człowiek jest ujmowany jako przypadłościowa jedność dwóch

${ }^{18}$ Historia antropologii i filozofii społecznej pokazuje, że dziejom dawnym i współczesnym towarzyszą błędne, tzn. redukcyjne koncepcje człowieka, pociągające za sobą niszczące konsekwencje zarówno dla życia jednostkowego, jak i społecznego. Jan Paweł II nazwał je w kontekście socjalizmu „błędem antropologicznym” (Jan Paweł II 1991; Sztaba 2014). 
różnych substancji: duszy i ciała, jak to było m.in. u Platona oraz Kartezjusza. Radykalny kartezjański dualizm (res cogitans i res extensa) wraz z filozofią cogito na dobre zadomowił się w nauce, sprawiając m.in., że filozofia wpadła w „pułapkę refleksji”, tracąc podstawowy przedmiot poznania, którym jest świat, zagłębiając się w meandry egotyczności (Sochoń 2007).

W związku z powyższymi twierdzeniami Piotr Jaroszyński zauważa, że dla uzasadnienia integralnej wizji człowieka i jego duchowości najtrudniejsza jest polemika $\mathrm{z}$ dualizmem, a nie $\mathrm{z}$ redukcjonizmem. Ten ostatni jest przynajmniej wewnętrznie koherentny: albo człowiek jest duchem, bo wszystko jest duchem, albo jest ciałem, bo wszystko jest materią. Redukcjonizm można podważyć, pokazując istotną różnicę pomiędzy aktami ducha i aktami ciała. Natomiast bardzo ciężko jest przezwyciężyć dualizm (Jaroszyński 2007).

Z pomocą w uzasadnieniu integralnej wizji człowieka przychodzi personalizm o inspiracji chrześcijańskiej, który prezentuje adekwatną antropologię (Sztaba 2014b).

\section{Drogi poznania duchowości osoby w kontekście integralnego doświadczenia człowieka}

Vittorio Possenti w prowadzonych przez siebie badaniach podkreśla, że dzisiaj problemy antropologiczne są bardziej złożone niż kiedykolwiek, dlatego też badacz powinien nauczyć się subtelnej sztuki pluralizmu metodologicznego, która respektuje fakt istnienia podejścia naukowo-empirycznego i podejścia metafizycznego do problemu człowieka. Nauki empiryczne w badaniu zjawisk stosują konceptualizacje właściwe dla porządku empirycznego, natomiast filozofia, wzbogacana namysłem teologicznym, dokonuje intelektualnego oglądu w porządku ontycznym. $\mathrm{Z}$ tego też powodu autor ten podał kilka metodologicznych twierdzeń, stojących u podstaw naukowo-filozoficznego podejścia do złożonej problematyki człowieka i jego duchowości.

Po pierwsze, należy jasno rozróżniać płaszczyznę realności od płaszczyzny poznania empirycznego, co w praktyce oznacza, że to, że coś nie jest postrzegane w obrębie badań empirycznych, nie jest równoznaczne z tym, że to nie istnieje.

Po drugie, płaszczyzna realna, ontyczna zawsze powinna mieć priorytet w stosunku do płaszczyzny epistemologicznej, czego konsekwencją jest m.in. uznanie słuszności metody fenomenologicznej w badaniach nad człowiekiem.

Po trzecie, osiągnięcia poznawcze nie charakteryzują jedynie nauk empirycznych, ale także filozofię i teologię, czemu jednak zaprzecza pozytywizm w swoich różnych wersjach.

Po czwarte, osoba ludzka jest rzeczywistością pierwotną w stosunku do tego, co ją otacza, co oznacza, że jest ona elementem podstawowych struktur świata życia, badanym przez nauki w sposób fragmentaryczny i aspektowy. Z tego też powodu powinno prowadzić się badania nie tyle abstrakcyjnej duszy i umysłu, co duszy 
i umysłu osoby i w osobie, która jest podmiotem zdolnym do intencjonalności poznawczej i wolitywnej.

Po piąte, należy bardzo świadomie dokonywać rozróżnień pomiędzy sferami ożywioną i nieożywioną. Jest to podstawowa opozycja wymagająca wypracowania koncepcji życia przy zastosowaniu nauk szczegółowych, jak również pojęć immanentnej formy i wewnętrznego tworzenia się (autopoiesis). Bez tego rozróżnienia życie zostaje sprowadzone do poziomu mechanizmu fizykalno-chemio-genetycznego (Possenti 2007).

Mając w pamięci te podstawowe, metodologiczne twierdzenia, pożyteczne w badaniach nad człowiekiem, w dalszej kolejności poszukujemy adekwatnych metod odkrywania i analizy duchowości osoby. Karol Wojtyła w swojej personalistycznej teorii osoby podkreśla, że to, co „nieredukowalne w człowieku”, można rozpoznać poprzez obiektywizację problemu podmiotowości osoby, szczególnie na terenie filozoficznej antropologii i etyki (Wojtyła 200ob) ${ }^{19}$. Obiektywizacja zaś powinna dokonywać się na gruncie integralnego doświadczenia człowieka, które „wyzwala nas siłą faktu od czystej świadomości jako podmiotu pomyślanego i założonego a priori, a wprowadza nas w cały konkret istnienia człowieka, tj. w rzeczywistość podmiotu świadomego” (Wojtyła 20oob). Jak bowiem pisze Karol Wojtyła, „bogactwo i różnorodność doświadczenia stanowią jak gdyby prowokację dla umysłu, aby rzeczywistość osoby i czynu raz pojętą starał się jak najwszechstronniej ująć i jak najpełniej wytłumaczyć. To jednakże może się dokonać tylko na drodze coraz głębszego wchodzenia w doświadczenie, w jego zawartość. Dzięki temu osoba i czyn zostają niejako wydobyte z mroku. Coraz pełniej i coraz wszechstronniej się wyłaniają, stając przed poznającym je umysłem" (Wojtyła 20ooa, s. 64).

Przedstawiciele Polskiej Szkoły Filozofii Klasycznej stoją na stanowisku empiryzmu genetycznego, twierdząc, że całe ludzkie poznanie rodzi się z doświadczenia, które jawi się jako naczelne źródło poznania, ponieważ jest bezpośrednim stykiem poznawczym z bytem. Wskazują na dwa główne typy doświadczenia: zewnętrzne i wewnętrzne, przy czym szczególną rolę w poznaniu człowieka in se przypisują doświadczeniu wewnętrznemu. Pierwszorzędnym przedmiotem poznania jest byt zewnętrzny w stosunku do podmiotu poznającego. Poznanie siebie samego przez podmiot poznający jest czymś wtórnym do tego pierwszego poznania. Każde doświadczenie wiąże się ściśle z funkcjonowaniem świadomości i jest w związku z tym faktem jakimś zrozumieniem (Dec 1994).

Karol Wojtyła zwracając uwagę na potrzebę doboru prawidłowej metody przyczyniającej się do wzbogacenia i pogłębienia całego realizmu koncepcji człowieka poprzez uchwycenie integralnego doświadczenia, wskazuje na dwie komplementarne metody: metafizyczną i fenomenologiczną (Wojtyła 2ooob).

19 Problematyka personalistyczna była dla Karola Wojtyły zasadnicza. Był on przekonany, że filozofia osoby ma podstawowe znaczenie dla poszczególnego człowieka i całej rodziny ludzkiej (Wojtyła 2000a). 
Metoda metafizyczna polega na systemowym wyjaśnianiu bytu ludzkiego w kontekście ogólnej metafizyki i ewentualnie filozofii przyrody ${ }^{20}$. Pozwala poznać „do końca” i zrozumieć złożoność człowieka, wskazując na niego jako byt złożony z duszy i ciała, podkreślając istotową niesprowadzalność ducha do materii. Metoda ta wyjaśnia rzeczywistość człowieka w sposób racjonalnie niesprzeczny, tj. w świetle pierwszych zasad bytu i myśli (zasady niesprzeczności, racji dostatecznej, tożsamości i wyłączonego środka). Mówi się wówczas o tzw. redukcji metafizycznej, która w myśl klasycznego adagium agere sequitur esse (byt mówi, wskazuje na działanie) interpretuje specyfikę somatycznych i psychiczno-umysłowych działań człowieka jako uzewnętrznienie oraz potwierdzenie istnienia wewnętrznego osobowego „ja”, jego psychofizycznej struktury, atrybutów oraz możliwości autoteleologii (Kowalczyk 2010; Wojtyła 20ooa).

Metoda metafizyczna, chociaż prezentuje całościową i racjonalnie niesprzeczną wizję człowieka zsynchronizowaną z ogólnym poglądem na świat, jest niewystarczająca, aby uchwycić cały fenomen osoby ludzkiej. Jest zbyt schematycznym i „odgórnym” spojrzeniem na osobę. Koncentruje się na ważnym, aczkolwiek przedmiotowym jej ujęciu, opisując językiem ontologicznym kategorie: bytu, substancji, aktu i możności, materii i formy, istnienia i istoty, duszy i materii. Dlatego Wojtyła, dostrzegając te braki, podkreślał potrzebę zastosowania w filozofii człowieka języka personalistycznego i aksjologicznego, który występuje w opisie świata ludzkiego i którym posługuje się metoda fenomenologiczna (Kowalczyk 2010).

Zdaniem Wojtyły metafizyczna analiza bytu ludzkiego (suppositum humanum) potrzebuje oglądu fenomenologicznego, który pozwoli w pełni zrozumieć compositum humanum jako jedną i bytowo niepowtarzalną osobę (Wojtyła 20ooa). Jeżeli owocem analizy metafizycznej jest poznanie duszy ludzkiej jako zasady jedności bytu i życia konkretnej osoby - gdzie o istnieniu duszy oraz o jej duchowej naturze wnioskujemy ze skutków - to dzięki metodzie fenomenologicznej możemy zapoznać się z treścią przeżycia duszy (Wojtyła 200oa). Zdaniem Wojtyły zatrzymać się poznawczo przy przeżyciu osoby ludzkiej to odkryć zarazem to, co w niej nieredukowalne. „Analiza fenomenologiczna służy więc zrozumieniu transfenomenalnemu, służy zarazem ujawnieniu tego bogactwa, jakie właściwe jest bytowi ludzkiemu w całej złożoności compositum humanum" (Wojtyła 20oob, s. 442).

Duchowość człowieka nie jest prostym mechanizmem, który można opisać naukowo. Dlatego Joseph Ratzinger przypomina, że jej punkt odniesienia znajduje się poza nią - w duszy, a punkt odniesienia duszy - w Bogu. Stąd jedynie w perspektywie Boga można dać adekwatną odpowiedź na pytanie o duchowo-cielesnego człowieka i jego duchowość (Składanowski 2013).

${ }^{20}$ Metoda metafizyczna jest charakterystyczna dla tradycyjnej antropologii filozoficznej zwanej filozofią przedmiotu, koncentrującej się na gatunkowym określeniu człowieka poprzez redukcję typu kosmologicznego - homo to animal rationale (Wojtyła 20oob). 


\section{Duchowość człowieka a dusza ludzka}

Osoba nie może przejawiać duchowości, jeśli w jakiś sposób nie jest duchem. Taki sposób rozumowania i wnioskowania wyznaczają podstawowe zasady rozumienia całej rzeczywistości (prima principia): zasada niesprzeczności i zasada racji wystarczającej. Jest to droga interpretacji człowieka w filozofii bytu, która szuka właściwego źródła i przyczyny danego zjawiska, a w naszym przypadku - duchowości. Tego domaga się model filozofii wyjaśniającej i redukcyjna droga postępowania, która przebiega od następstwa do racji (od skutku do przyczyn). Chodzi więc o wskazanie bliższych i dalszych ontycznych racji duchowości człowieka (Dec 1994).

Bliższą racją tłumaczącą duchowość osoby są jej umysłowe władze/zdolności: intelekt (świadomość oraz samoświadomość) i wola, które odpowiadają za ponadzmysłowe akty poznawcze i wyższe akty pożądawcze (Dec 1994; Maryniarczyk 2007). Rację zaś wewnętrzną i ostateczną dla wszelkiej działalności człowieka, a w szczególności dla działań intelektualno-wolitywnych, stanowi dusza ludzka (Dec 1994; 2007). W związku z powyższymi stwierdzeniami Karol Wojtyła napisze, że „wszystkim zaś przejawom duchowości człowieka [...] musi odpowiadać realna immanencja ducha, pierwiastka duchowego w człowieku. Człowiek nie może przejawiać duchowości, jeśli w jakiś sposób nie jest duchem. Za takim postawieniem sprawy przemawiają podstawowe zasady rozumienia całej rzeczywistości: zasada niesprzeczności i racji wystarczającej" (Wojtyła 20ooa, s. 224).

Jeśli analiza fenomenologiczna pozwala uchwycić duchowość osoby w postaci transcendencji osoby w czynie, to analiza metafizyczna wskazuje na człowieka jako byt duchowo-cielesny ${ }^{21}$. Nie sposób bowiem pojąć ani wyjaśnić przejawów duchowości w człowieku bez substancjalności - owej stałości pierwiastka duchowego w nim, tj. duszy ludzkiej ${ }^{22}$.

Nie analizując problemu istnienia i istoty duszy ludzkiej - gdyż można odwołać się do dostępnych na ten temat publikacji (Judycki 2010; Mazur 2013; Składanowski 2013) - należy stwierdzić, że dusza ludzka jest: a) ostateczną i wewnętrzną racją oraz

${ }^{21}$ Karol Wojtyła pisze, że „Zarówno sama rzeczywistość duszy, jak też rzeczywistość jej stosunku do ciała są w tym sensie rzeczywistością trans-fenomenalną i poza-doświadczalną. Równocześnie jednak całościowe i wszechstronne zarazem doświadczenie człowieka naprowadza nas na tę rzeczywistość, i to zarówno na rzeczywistość duszy, jak też jej stosunku do ciała. I nie na żadnej innej drodze, tylko na drodze doświadczenia człowieka i jedna, i druga rzeczywistość została odkryta i stale bywa odkrywana metodą refleksji filozoficznej właściwej filozofii bytu, czyli metafizyce" (Wojtyła 2000a, s. 298). Prezentację metafizycznej analizy natury człowieka (duchowości i cielesności) znajdujemy u Marii Małgorzaty Boużyk (Boużyk 2013).

22 Zagadnieniem duszy od początku zajmowała się metafizyka, wskazując na człowieka jako byt złożony z duszy i ciała. Wielkie zasługi w tej materii ma Arystoteles, a później św. Tomasz z Akwinu, który uczył o istotowej niesprowadzalności ducha do materii i relacjach zachodzących pomiędzy nieśmiertelną duszą a materialnym ciałem, opisywanych według teorii hylemorfizmu (Krąpiec 2007; Wojtyła 2000a). 
właściwym podmiotem dla aktów poznawczych intelektu i aktów pożądawczych woli $^{23}$; b) pierwszą i jedyną zasadą życia; c) aktem i samoistną formą substancjalną ciała (jego organizatorką i formatorką); d) racją bytowej jedności człowieka; d) samoistną formą „wypowiadającą się” poprzez materialne ciało, będąc samoistnym, duchowym, niezależnym w zaistnieniu od ciała podmiotem (Dec 1994; Maryniarczyk 2005).

Dusza jest więc czynnikiem konstytuującym osobę. Odpowiada ona za integrację osoby w czynie, która jest komplementarnym aspektem transcendencji (Dec 1994). We wspomnianej integracji chodzi o podporządkowanie dynamizmu somatycznego (m.in. popędów) i psychicznego (emotywności i emocjonalności) kontroli rozumu i woli tak, aby te dynamizmy brały czynny udział w samostanowieniu, czyli w urzeczywistnianiu się wolności osoby ludzkiej ${ }^{24}$. Karol Wojtyła analizując i opisując transcendencję i integrację osoby w czynie, zauważa i podkreśla, że chociaż te procesy przebiegają przez ciało i w nim się wyrażają, to swoje źródło mają w duszy ludzkiej, która jest ich ostateczną zasadą. Osoby ludzkiej nie można bowiem utożsamiać z samym tylko ciałem (Mizdrak 2010; Wojtyła 200oa).

\section{Transcendencja jako przejaw duchowości osoby ludzkiej}

Integralne doświadczenie człowieka jawi się jako poznawcze źródło transcenden$\mathrm{cji}^{25}$. Analizując to doświadczenie, badacz napotyka na dynamizmy somatyczno-wegetatywne, psycho-emotywne oraz osobowe (duchowe), które są: a) realnie istniejącymi niesprowadzalnymi do siebie faktami; b) mają własną treściową zawartość; c) są bezpośrednio poznawane (Dec 1994). Dynamizmy osobowe związane z podmiotowością, świadomością, sprawczością i samostanowieniem (Sztaba 2013) naprowadzają na fenomen transcendencji (Dec 1994).

Dla Karola Wojtyły transcendencja to „drugie imię osoby”, bowiem najpełniej ukazuje ona najgłębsze warstwy struktury osoby (Wojtyła 20oob), stając się tym samym znakiem duchowości człowieka (Wojtyła 200oa). Przywoływany filozof

${ }^{23}$ Rozum i wola są władzami natury duchowej o charakterze dynamicznym i potencjalnym (Wojtyła 2000a).

${ }^{24}$ Między samorzutnym dynamizmem ludzkiej psychiki (uczucia, podniecenie, namiętności) a sprawczością osoby zarysowuje się wyraźne napięcie. Karol Wojtyła określa je jako twórcze napięcie pomiędzy uczuciem a wolą, domagające się integracji osoby w czynie (Wojtyła 20ooa).

25 Termin „transcendencja” należy rozumieć jako „przekraczanie”, „wyższość” bytową osoby wobec natury, przy metafizycznym rozumieniu pojęć osoby i natury (Dec 1994). Rozumienie pojęcia transcendencji zależy od całościowej koncepcji filozoficznej, której jest częścią. Dobrze tę prawdę ilustruje artykuł Katarzyny Wrońskiej, w którym autorka analizuje ujęcie transcendencji w klasycznej metafizyce, w filozofii dialogu oraz w filozofii świadomości (Wrońska 2010). $\mathrm{W}$ dobie postmodernizmu neguje się naturę, co powoduje wiele trudności i niebezpiecznych konsekwencji dla poszczególnego człowieka i całych społeczeństw (Maryniarczyk, Stępień, Gudaniec 2014). 
opisuje dwa podstawowe znaczenia terminu „transcendencja” związane z metafizyką i teorią poznania, i w związku z tym wyróżnia transcendencję poziomą i pionową.

Transcendencja pozioma to przekraczanie własnej podmiotowości w kierunku przedmiotu. Dokonuje się ona zarówno w aktach poznawczych, jak też w aktach woli (chcenia). Odznaczają się one intencjonalością, ponieważ są skierowane ku przedmiotom. Autor określa je jako transcendencję poznawczą i transcendencję wolitywną.

Fundamentalnym elementem transcendencji poznawczej osoby jest zdolność umysłu do ujmowania prawdy o rzeczywistości, szczególnie zaś o dobru, oraz prawdy o przedmiotach jako wartościach-dobrach. Prawda ta ujawnia się w funkcjonowaniu sumienia. Rodzi zarazem powinność, wskazując na zależność dobra od prawdy. Przeżywana zaś powinność staje się warunkiem zaistnienia odpowiedzialności (Wojtyła 2oooa).

Wyrazem transcendencji wolitywnej, tzn. „wychodzenia” jednej osoby do drugiej, są akty miłości. W metafizyce, rozważając naturę aktu miłości oraz jej twórczą funkcję, mówi się o bytowym charakterze miłości. Zdaniem Wojtyły osoba ludzka transcenduje w aktach miłości dzięki temu, że w miłości ludzkiej obecne są elementy poznania (prawdy) i wolności (Dec 1994).

Transcendencja pionowa, jako ta właściwa, zapewnia osobie ludzkiej szczególne miejsce w przyrodzie. Polega ona na zwróceniu się podmiotu ku swojemu wnętrzu, gdzie odkrywa on siebie jako przyczynę własnego działania. Transcendencja ta ujawnia się przede wszystkim w samostanowieniu ${ }^{26}$. Wskazuje na właściwą transcendencję osoby w czynie, wyrażając istotną treść doświadczenia „człowiek działa”, która określa nadrzędność „ja” osoby wobec własnego dynamizmu²7.

Transcendencja osoby w czynie określa więc szczególny rys struktury człowieka jako osoby-podmiotu, tzn. jego swoistą nadrzędność w stosunku do samego siebie

${ }^{26}$ Samostanowienie jest czynnikiem ujawniającym strukturę samoposiadania, która z kolei jest warunkiem samopanowania. Aby człowiek mógł o sobie stanowić, musi siebie samego posiadać i sobie samemu panować. Samostanowienie implikuje więc określone struktury osoby. Samopanowanie oznacza właściwość osoby, dzięki której panuje ona nad własnymi dynamizmami. Samoposiadanie zaś to własność, mocą której osoba jest swoistą własnością - sama siebie posiada. Właściwość ta jest bardziej pierwotna niż samopanowanie. Struktury samopanowania i samoposiadania stanowią o człowieku jako osobie. One decydują o jego ontologicznej oryginalności, będąc podstawą transcendencji. Samostanowienie w ujęciu Karola Wojtyły to wolność rozumiana w znaczeniu podstawowym (Wojtyła 2000a).

27 Zagadnienie transcendencji pionowej jest fundamentalne dla koncepcji wychowania moralnego i podstawowych wartości (dobra, prawdy, wolności). Transcendencja pionowa ujawnia swój dynamizm w kontekście intencjonalnych aktów poznania i chcenia, gdzie intelekt jest czynnikiem ukierunkowującym dynamizm woli. Jest to więc transcendencja przez sam fakt wolności - bycia wolnym w działaniu - którą zawdzięczamy samostanowieniu. Transcendencja pionowa jest właściwa nie tylko aktowi woli, ale obejmuje także akt poznawczy intelektu (Dec 1994; Wojtyła 200oa). 
i swoich różnych dynamizmów. Osoba dokonuje transcendencji natury poprzez duchowe akty poznania intelektualnego, miłości i wolności oraz akty religijne, objawiając tym samym swoją duchowość (Dec 1994).

Dzięki doświadczeniu fenomenologicznemu przekonanie o duchowości człowieka nie jest wynikiem jakiejś abstrakcji, ale ma swój kształt oglądowy, bowiem „duchowość jest otwarta dla oglądu, a także dla wglądu. Ów kształt - kształt transcendencji - jest konkretnym kształtem istnienia człowieka, owszem, jest kształtem życia. Człowiek jako osoba żyje i spełnia siebie w tym kształcie” (Wojtyła 2000a, s. 223).

\section{Duchowość religijna/życie duchowe a doświadczenie religijne i wiara}

Duchowość naturalna, będąc zapodmiotowiona w duszy, nie wyczerpuje się w kulturze (Sztaba 2015). Życie duchowe związane jest bowiem także z doświadczeniem religijnym i wiarą (Moskal 2014; Stal 2001; Sztaba 2014b). Metafizyczne wyjaśnianie i rozumienie religii oraz religijności w odwołaniu do struktury ontycznej człowieka (byt przygodny i potencjalny) pozwala dostrzec znamienny fakt, że „religia jako osobowe odniesienie człowieka do Boga jako celu ostatecznego stanowi oś, czyli fundament moralnego dynamizmu człowieka. Toteż eliminacja tego odniesienia to nie tylko pominięcie jakiegoś segmentu moralności, ale przebudowa, a właściwie destrukcja porządku moralnego" (Boużyk 2013).

Związki religii i moralności są widoczne szczególnie w chrześcijaństwie, dzięki czemu ma ono moc zapewniania życiu ludzkiemu pełni i szczęścia, wpływając w sposób istotny na osiągnięcie przez człowieka dojrzałości. Étienne Gilson, komentując teologię moralną św. Tomasza, zauważył, że moralność bez religii jest oczywiście możliwa, ale dla chrześcijanina pozostaje niedorzecznością (Boużyk 2013). Prawdą jest i to, że nie można redukować religii tylko do moralności ani pozbawiać moralności religijnego kontekstu (Sztaba 2012; 2014b).

Z religią - obok moralności - wiąże się w sposób organiczny religijność. Doświadczenie zewnętrzne i wewnętrzne faktu ludzkiego pozwala stwierdzić filozofom tradycji realistycznej, że człowiek z natury jest otwarty na absolut - Boga (capax Dei), przez co religijność jest jego naturalną inklinacją (Boużyk 2013; Chrost 2013). Ponieważ integralny rozwój człowieka oznacza wieloaspektową realizację osobowych potencjalności (poznawczych, moralnych, społecznych, twórczych i religijnych), to religijność można rozumieć jako sprawność moralną (cnotę), która kształtuje się w konkretnych aktach religijnych (ascezie, modlitwie itp.) i do rozwoju potrzebuje kontekstu określonej religii, bowiem nie ma religijności poza konkretną religią. Religijność jest więc aktualizowaniem ludzkich potencjalności, w tym religijnych, poprzez usprawnianie ludzkiego działania i jego źródeł, tj. władz duchowych (Boużyk 2013).

Związek duchowości z religią jest wyraźnie widoczny w religii chrześcijańskiej (Sztaba 2014b). Źródłem duchowości chrześcijańskiej jest objawienie zawarte 
w Piśmie Świętym, aktualizowane i urzeczywistniane w liturgii i we wspólnocie Kościoła. Chrześcijańskie życie duchowe ma wymiar naturalny, bo angażuje rozum, wolę i uczucia osoby, oraz nadprzyrodzony, bo związane jest z Bogiem trójjedynym i Jego łaską udzielaną w sposób szczególny w sakramentach.

Życie duchowe chrześcijan naznaczone jest powszechnym powołaniem do świętości, tzn. wezwaniem do uczestnictwa w życiu samego Boga poprzez dorastanie do doskonałości moralnej wyrażonej w autentycznej miłości, tzn. byciu bezinteresownym darem $z$ samego siebie ${ }^{28}$. Ponieważ są różne drogi dochodzenia do świętości, dlatego też możliwy jest pluralizm form życia duchowego, na co wskazują charyzmaty różnych zakonów i zgromadzeń zakonnych oraz duszpasterstwa poszczególnych grup: kobiet, dzieci, młodzieży, dorosłych, chorych, grup zawodowych (poszczególne zawody posiadają sobie właściwą formę duchowości chrześcijańskiej).

\section{Pedagogia osoby wobec potencjalności duchowości człowieka}

Pedagogia osoby, dążąc do integralnego rozwoju człowieka, zawsze powinna uwzględniać kilka podstawowych faktów i postulatów.

Po pierwsze, duchowość człowieka jest faktem ogólnoludzkim, a więc ważnym elementem antropologii, która jawi się jako podstawowa i niezwykle trudna kwestia społeczna (Possenti 2007) ${ }^{29}$. Współczesna „ślepota ducha” czy nawet „śmierć duszy", afflictio animarum (przygnębienie duszy) dostrzegane w depresji (Possenti 2007), domagają się zajęcia jasnego i merytorycznego stanowiska w obronie duszy i duchowości (Michałowski 2004; Składanowski 2013).

Po drugie, realne i integralne rozumienie człowieka jako osoby wskazuje na dynamiczny i potencjalny charakter jego duchowości. Sytuacja ta związana jest z dynamicznością i potencjalnością rozumu i woli, które jako władze duszy są natury duchowej. Wychowywać rozum i wolną wolę to przyczyniać się do tego, aby w życiu każdego człowieka dokonywała się transcendencja i integracja osoby w czynie. Procesy te trwają całe życie i jawią się jako podstawowe zadanie dla pedagogii osoby w kontekście integralnego kształcenia i wychowania. Chociaż zadanie to brzmi jako nowe i bardzo trudne do realizacji, to w rzeczywistości jest ono organicznie związane z klasycznym poniekąd postulatem kształcenia charakteru,

${ }^{28}$ W świetle analiz filozofii realistycznej świętość jawi się jako wartość-dobro-doskonałość „nabudowana" na innych wartościach humanistycznych, szczególnie na transcendentaliach: prawdzie, dobru i pięknie. Świętość jest wartością swoistą, która implikuje i przenika inne wartości. Jest formą je ożywiającą i stanowi ich swoiste spełnienie, ponieważ pozbawione ostatecznego horyzontu, głębi i właściwych perspektyw są skazane na martwotę. Wartości mogą w pełni urzeczywistniać się przez akt miłości w stosunku do Boga-Absolutu, który jest osobą transcendentną, duchową i wieczną (Boużyk 2013).

29 Na trud badań nad człowiekiem zwracali uwagę m.in. Błażej Pascal w Myślach i David Hume w Traktacie o naturze ludzkiej (Possenti 2007). 
w skład którego wchodzą formacja rozumu, woli i uczuć oraz sumienia (Ceglarek, Sztaba 2015; Piątkowska, Stępień 2005; Sztaba 2014b).

Po trzecie, istnieje realna możliwość utraty życia duchowego, czego zewnętrznym przejawem jest brak poczucia sensu i całkowite zwątpienie, o czym pisali Paul Tillich i Victor E. Frankl (Kostkiewicz 2004). Dlatego pedagogia osoby powinna uwzględniać twierdzenia logoterapii, zapobiegając utracie przez człowieka poczucia sensu ${ }^{30}$.

Po czwarte, redukcyjne koncepcje człowieka (Krąpiec 2007; Sztaba 2014b) generują m.in. fałszywą duchowość. Zjawisko to dotyczy zarówno duchowości naturalnej, jak i religijnej ${ }^{31}$, określanej mianem „bezdroży duchowości” (Pawłowicz 2002). Taka duchowość tworzona jest w atmosferze postmodernizmu, dla którego jedyną zasadą jest brak zasad, a naczelnymi wartościami są pluralizm, tolerancja i różnica.

Po piąte, ponieważ duchowość człowieka - zarówno naturalna, jak i religijna ma charakter rozwojowy, należy w sposób profesjonalny i interdyscyplinarny opracować program kierownictwa duchowego, dostosowany do wieku, potrzeb i sytuacji życiowej poszczególnych osób (Michałowski 2004; Surzykiewicz 2015). Pomocą w tym dziele może być teoria warstwicowego rozwoju osoby (Karczewska

${ }^{30}$ W świetle logoterapii, której twórcą jest Victor E. Frankl, urzeczywistnianie się człowieka dokonuje się nie poprzez realizację „zasady przyjemności” (Z. Freud) czy też „zasady mocy”, tj. dążenia do wyższości (A. Adler), ale poprzez wolę sensu. Człowiek w gruncie rzeczy nie dąży do przyjemności i szczęścia jako takich, ale do spełnienia osobistego sensu, zbliżenia się do drugiego człowieka, dzięki czemu może przeżywać szczęście i przyjemność. Logoterapeutyczna koncepcja człowieka opiera się na trzech filarach: wolnej woli, woli sensu i sensu życia. Otwarcie się człowieka na wymiar noologiczny chroni go przed egzystencjalną pustką i poczuciem bezsensu, pozwalając zmierzyć się z tzw. tragiczną trójcą ludzkiej egzystencji: bólem, śmiercią oraz winą. Niewątpliwie osoby poszukującej sensu życia i rozwijającej w sobie wolę sensu nie ogarnie osamotnienie czy też samotność moralna. Dlatego Frankl twierdzi, że podstawowym zadaniem psychiatrii naszych czasów jest wyposażenie człowieka w umiejętność odnajdywania w nim samym sensu życia. $Z$ tego też powodu logoterapia jawi się jako odpowiedź na duchowe potrzeby współczesnego człowieka (Frankl 2010, s. 9-24), a zagadnienie poczucia sensu jako wielkie wyzwanie dla współczesnej pedagogiki, jeśli w rzeczywistości zabiega się o integralne dobro rozwojowe człowieka (Michalski 2011).

${ }^{31}$ Benedykt XVI wskazując w encyklice Caritas in veritate na religię jako istotny czynnik w integralnym rozwoju ludzkim zarówno w wymiarze jednostkowym, jak i społecznym, bardzo zdecydowanie podkreślił, że nie wszystkie religie służą rozwojowi człowieka, kierując się w swoim nauczaniu i działaniu kryterium prawdy i miłości według zasady „cały człowiek i wszyscy ludzie”. Niektóre religie zamykają „społeczeństwo w statycznych kastach społecznych, w magicznych wierzeniach, lekceważących godność osoby ludzkiej, w postawach uległości wobec tajemnych sił". Ponadto w dobie pluralizmu kultur i religii oraz synkretyzmu religijnego nowe ruchy religijne (sekty, duchowość pogranicza itd.) oraz pewne kultury o podłożu religijnym „nie przyjmują w pełni zasady miłości i prawdy, i w konsekwencji hamują prawdziwy rozwój ludzki albo wprost mu przeszkadzają" lub izolują człowieka „w poszukiwaniu indywidualnego dobrobytu, ograniczając się do zaspokojenia jego oczekiwań psychologicznych", stają się przez to „czynnikiem rozproszenia i braku zaangażowania” (Benedykt XVI 2009, nr 55). 
2012; Nowak, Ożóg, Rynio 2003) oraz świadomość, że wychowanie samo w sobie jest procesem duchowym (Sztaba 2015a; Śliwerski 2012).

Po szóste, naturalna duchowość jest podstawą dla duchowości religijnej dzięki temu, że otwiera osobę na Absolut, który jest fundamentem dla jej duchowego bytu. Pedagogia osoby powinna być wrażliwa na tę duchowość, szczególnie rozwijaną w procesie wychowania religijnego, które wskazuje na wezwanie człowieka do zbawienia - życia wiecznego. Wychowanie religijne idzie bowiem dalej niż każda inna dziedzina wychowania, bo przygotowuje osobę do ukształtowania w sobie pewnej ogólnej wizji świata, wyrobienia światopoglądu i dążenia do celu ostatecznego (Boużyk 2014; Marek 2015; Sztaba 2014b).

W świetle zaprezentowanych w artykule refleksji, można stwierdzić, że autentyczna pedagogia osoby powinna być wrażliwa zarówno na naturalną, jak i religijną duchowość człowieka. Pedagogia osoby musi być także świadoma różnych wersji fałszywej duchowości, które w gruncie rzeczy godzą w integralny rozwój człowieka. Tak uprawiana pedagogia osoby może przyczynić się do skutecznego pokonywania współczesnego wielopostaciowego kryzysu, u podstaw którego znajduje się kryzys autentycznej duchowości.

\section{Bibliografia}

Ablewicz K. (2010). Aksjologiczny „mechanizm” życia duchowego - studia z zakresu antropologii filozoficzno-pedagogicznej z perspektywy filozofii kultury Bogdana Nawroczyńskiego. W: Nowak M., Magier P., Szewczak I. (red.). Antropologiczna pedagogika ogólna. Lublin: Wydawnictwo Gaudium, s. 219-231.

Boużyk M.M. (2013). Wychowanie otwarte na religię. Polska Szkoła Filozofii Klasycznej o roli religii w wychowaniu. Warszawa: Wydawnictwo UKSW.

Ceglarek R., Sztaba M. (red.). (2015). Być człowiekiem sumienia. Interdyscyplinarny namysł nad fenomenem sumienia. Częstochowa: Wydawnictwo Archidiecezjalne Regina Poloniae.

Chrost S. (2013). Homo capax Dei jako ideał wychowania. Kraków: Wydawnictwo „Impuls".

Chudy W. (2007). Antropologiczne koncepcje ducha absolutnego w XX wieku. W: Maryniarczyk A., Stępień K. (red.). Dusza - umyst - ciało. Spór o jedność bytowa człowieka. Lublin: Polskie Towarzystwo Tomasza z Akwinu, s. 297-323.

Dec I. (2007). Doświadczenie bytowej jedności człowieka. W: Maryniarczyk A., Stępień K. (red.). Dusza - umyst - ciało. Spór o jedność bytowa człowieka. Lublin: Polskie Towarzystwo Tomasza z Akwinu, s. 487-512.

Dec I. (1994). Transcendencja człowieka w przyrodzie. Wrocław: Wydawnictwo PFT. Frankl V.E. (2012). Bóg ukryty. W poszukiwaniu ostatecznego sensu, tłum. Wolnicka A. Warszawa: Wydawnictwo Czarna Owca.

Frankl V.E. (2010). Wola sensu. Założenia i zastosowanie logoterapii, tłum. Wolnicka A. Warszawa: Wydawnictwo Czarna Owca. 
Hejnicka-Bezwińska T. (2008). Pedagogika ogólna. Warszawa: Wydawnictwa Akademickie i Profesjonalne.

Jan Paweł II (1991). Encyklika Centesimus annus. W stulecie encykliki Leona XIII Rerum novarum.

Jan Paweł II (1999). List do artystów.

Janeczek S. (2001). Filozofia na KUL-u. Nurty - osoby - idee. Lublin: Redakcja Wydawnictw KUL.

Jaroszyński P. (2007). Personalizm filozoficzny - integralna wizja człowieka. W: Maryniarczyk A., Stępień K. (red.). Dusza - umyst - ciało. Spór o jedność bytowa człowieka. Lublin: Polskie Towarzystwo Tomasza z Akwinu, s. 473-486. Judycki S. (2010). Istnienie i natura duszy ludzkiej. W: Janeczek S. (red.). Antropologia. Lublin: Wydawnictwo KUL, s. 121-177.

Karczewska J. (2012). Integralne wychowanie - chrześcijańska koncepcja Stefana Kunowskiego. Kielce: Wydawnictwo UJK.

Kłoczowski J.A. (2001). Duchowość dzisiaj - wprowadzenie. W: Stal J. (red.). Duchowość dzisiaj - kontekst religijny i kulturowy. Kraków: Wydawnictwo PAT, s. 5-8.

Kostkiewicz J. (2004). Duchowość jako wartość i obszar wspierania rozwoju człowieka dorosłego. W: Kostkiewicz J. (red.). Aksjologia edukacji dorosłych. Lublin: Wydawnictwo KUL, s. 141-152.

Kostkiewicz J. (2003). Warstwa duchowa $w$ teoriach pedagogicznych XX wieku W. Flitner, S. Hessen, S. Kunowski. W: Nowak M., Ożóg T., Rynio A. (red.). W trosce o integralne wychowanie. Lublin: Wydawnictwo KUL, s. 175-186.

Kowalczyk S. (2010). Antropologia filozoficzna - koncepcja, metody, problematyka. W: Janeczek S. (red.). Antropologia. Lublin: Wydawnictwo KUL, s. 17-42.

Kowalczyk S. (2004). Idee filozoficzne postmodernizmu. Radom: Polwen.

Krąpiec M.A. (200o). O chrześcijańską kulturę. Lublin: Instytut Edukacji Narodowej. Krąpiec M.A. (2007). Rozumienie człowieka - od hinduizmu do New Age. W: Maryniarczyk A., Stępień K. (red.). Dusza - umyst - ciało. Spór o jedność bytowa człowieka. Lublin: Polskie Towarzystwo Tomasza z Akwinu, s. 17-42.

Kunowski S. (2001). Podstawy współczesnej pedagogiki. Warszawa: Wydawnictwo Salezjańskie.

Kuźniarz B. (2011). Goodbye Mr. Postmodernism. Teorie społeczne myślicieli późnej lewicy. Toruń: Wydawnictwo Naukowe UMK.

Makselon J. (2001). Psychologia bez dusz? W: Stal J. (red.). Duchowość dzisiaj - kontekst religijny i kulturowy. Kraków: Wydawnictwo PAT, s. 75-77.

Marek Z. (2015). Duchowość, religia i wychowanie. „Pedagogika Społeczna”, nr 1, s. 9-22.

Mariański J. (2009). Wychowanie ku wartościom religijnym. Perspektywa socjologiczna. W: Chałas K., Maj A., Mariański J. (red.). Wychowanie ku wartościom religijnym. Elementy teorii i praktyki. T. 4. Kielce: Wydawnictwo „Jedność”. 
Marszałek L. (2013a). Duchowość dziecka. Znaczenia - perspektywy - konteksty w pedagogice przedszkolnej. Warszawa: Wydawnictwo Szkoły Wyższej im. B. Jańskiego.

Marszałek L. (2013b). Działania transgresyjne wyrazem duchowej natury dziecka $w$ wieku przedszkolnym. "Seminare”, t. 33, s. 179-191.

Maryniarczyk A. (2005). Realistyczna interpretacja rzeczywistości. Lublin: Polskie Towarzystwo Tomasza z Akwinu.

Maryniarczyk A., Stępień K., Gudaniec A. (red.). (2014). Spór o naturę ludzką. Lublin: Polskie Towarzystwo Tomasza z Akwinu.

Maryniarczyk A. (2007). Źródła różnorodnych koncepcji jedności bytowej człowieka. W: Maryniarczyk A., Stępień K. (red.). Dusza - umyst - ciało. Spór o jedność bytowa człowieka. Lublin: Polskie Towarzystwo Tomasza z Akwinu, s. 71-96.

Mazur P.S. (2013). Geneza duszy ludzkiej w ujęciu klasycznym. W: Mazur P.S. (red.). Wokół genezy człowieka. Studia i rozprawy. Kraków: Wydawnictwo WAM, s. 31-53.

Michałowski S.C. (2004). Pedagogia rozwoju duchowego człowieka jako nadzieja współczesnych czasów. W: Kostkiewicz J. (red.). Aksjologia edukacji dorosłych. Lublin: Wydawnictwo KUL, s. 215-244.

Mizdrak I. (2010). Osoba i natura w ujęciu Karola Wojtyły. W: Duchliński P., Hołub G. (red.). Oblicza natury ludzkiej. Studia i rozprawy. Kraków: Wydawnictwo WAM, s. 137-158.

Moskal P. (2014). Traktat o religii. Lublin: Wydawnictwo KUL.

Nowak M., Ożóg T., Rynio A. (red.). (2003). W trosce o integralne wychowanie. Lublin: Wydawnictwo KUL.

Pawluczuk W. (2004). Duchowość. W: Libiszowska-Żółtkowska M., Mariański J. (red.). Leksykon socjologii religii. Zjawiska - badania - teorie. Warszawa: Verbinum, s. 90-92.

Pawłowicz Z. (2002). Bezdroży duchowość. W: Chmielewski M. (red.). Leksykon duchowości katolickiej. Lublin: Wydawnictwo „M”, s. 77-80.

Piątkowska A., Stępień K. (red.). (2005). Wychować charakter. Lublin: Wydawnictwo Gaudium.

Possenti V. (2007). Spór o jedność człowieka i wyzwania nowego naturalizmu. Dusza - umysł - ciało. W: Maryniarczyk A., Stępień K. (red.). Dusza - umysł ciało. Spór o jedność bytowa człowieka. Lublin: Polskie Towarzystwo Tomasza z Akwinu, s. 97-152.

Składanowski M. (2013). Ciało - dusza - duch. Myśl Josepha Ratzingera na tle współczesnej antropologii. Warszawa: Wydawnictwo Sióstr Loretanek.

Socha P. (200o). Psychologia rozwoju duchowego - zarys zagadnienia. W: Socha P. (red.). Duchowy rozwój człowieka. Fazy życia - osobowość - wiara - religijność. Kraków: Wydawnictwo UJ, s. 15-32. 
Sochoń J. (2007). Dualizm antropologiczny - źródła i konsekwencje. W: Maryniarczyk A., Stępień K. (red.). Dusza - umyst - ciało. Spór o jedność bytową człowieka. Lublin: Polskie Towarzystwo Tomasza z Akwinu, s. 443-472.

Stal J. (red.). (2001). Duchowość dzisiaj - kontekst religijny i kulturowy. Kraków: Wydawnictwo PAT.

Surzykiewicz J. (2015). Religia, religijność i duchowość jako zasoby osobowe i kapitał społeczny w pedagogice społecznej/pracy socjalnej. „Pedagogika Społeczna”, nr 1, s. 23-72.

Sztaba M. (red.). (2014a). Benedykt XVI. «Aby na nowo odkryć radość w wierze...». Antologia papieskich wypowiedzi na temat wiary, watpienia i ateizmu. Warszawa: Oficyna Wydawniczo-Poligraficzna ADAM.

Sztaba M. (2013). Jaka pedagogika i jaka duchowość? W poszukiwaniu adekwatnej, realnej i integralnej koncepcji pedagogiki. W: Bartoszewski J., Swędrak J., Struzik E. (red.). Wychowanie: czy może „obejść się” bez duchowości? Sieradz: WSHE, s. 114-134.

Sztaba M. (2015a). Wychowanie jako „twórczość o przedmiocie najbardziej osobowym” w myśli Karola Wojtyły - Jana Pawła II. W: Sztaba M., Różyło A. (red.). Wychowanie w refleksji Karola Wojtyły - Jana Pawła II. Wybrane aspekty. Lublin: Wydawnictwo KUL, s. 51-66.

Sztaba M. (2014b). Zagadnienie duchowości i religijności w integralnym wychowaniu osoby. W: Opiela M.L., Świdrak E., Łobacz M. (red.). Wychowanie integralne w edukacji katolickiej. Idee - twórcy - instytucje. Lublin: Wydawnictwo KUL, s. $61-85$.

Sztaba M. (2015b). Życie duchowe $w$ refleksji B. Nawroczyńskiego a rozumienie duchowości w świetle analiz Polskiej Szkoły Filozofii Klasycznej w kontekście współczesnej percepcji zjawiska duchowości [w druku w Wydawnictwie UŁ].

Śliwerski B. (2012). Pedagogika ogólna. Podstawowe prawidłowości. Kraków: Oficyna Wydawnicza „Impuls”.

Śliwerski B. (2011). Współczesna myśl pedagogiczna. Znaczenia, klasyfikacje, badania. Kraków: Oficyna Wydawnicza „Impuls”.

Werbiński I. (1993). Jedność i wielość duchowości. W: Igielski M. (red.). Teologia duchowości katolickiej. Lublin: Redakcja Wydawnictw KUL, s. 70-84.

Wojtyła K. (2000a). Osoba i czyn. W: Wojtyła K. „Osoba i czyn” oraz inne studia antropologiczne. Lublin: Towarzystwo Naukowe KUL, s. 43-344.

Wojtyła K. (20oob). Podmiotowość i „to, co nieredukowalne” w człowieku. W: Wojtyła K. „Osoba i czyn” oraz inne studia antropologiczne. Lublin: Towarzystwo Naukowe KUL, s. 433-443.

Wrońska K. (2010). Człowiek $w$ doświadczeniu wielowymiarowej transcendencji. W: Nowak M., Magier P., Szewczak I. (red.). Antropologiczna pedagogika ogólna. Lublin: Wydawnictwo Gaudium, s. 175-188.

Zdybicka Z. (2007). Bóg czy sacrum? Lublin: Polskie Towarzystwo Tomasza $\mathrm{z}$ Akwinu. 
Zohar D., Marshall I. (2001). Inteligencja duchowa, tłum. Turski P. Poznań: Dom Wydawniczy REBIS.

\title{
THE PEDAGOGY OF A PERSON TOWARDS THE ISSUE OF SPIRITUALITY
}

\begin{abstract}
We cannot talk about the realistic pedagogy of a person without considering its appropriate spirituality and religious education, being its simple consequence. The suggested article presents the issue of a person's spirituality based on the analysis of the realistic philosophy of existence, enriched with critically accepted philosophy of consciousness. The article discusses the issue of spirituality of a person, indicates also its numerous threats as well as pedagogical implications.
\end{abstract}

Key words: person, soul, spirituality, transcendence, religious education

Mariusz Sztaba - ksiądz, doktor pedagogiki, licencjat kanoniczny teologii dogmatycznej; adiunkt w Katedrze Pedagogiki Społecznej Katolickiego Uniwersytetu Lubelskiego Jana Pawła II. Obszary zainteresowań badawczych: pedagogika społeczna, pedagogika ogólna, pedagogika chrześcijańska oraz katolicka nauka społeczna. Publikacje książkowe: Tolerancja, ale jaka? Koncepcja wychowania do tolerancji w świetle nauczania Jana Pawła II do Polaków (2006), Troska bł. Jana Pawła II o etyczno-moralne podstawy życia społecznego (2011), Wychowanie społeczne w świetle nauczania Karola Wojtyły - Jana Pawła II (2012), Benedykt XVI. „Aby na nowo odkryć radość w wierze...”. Antologia papieskich wypowiedzi na temat wiary, wattpienia i ateizmu (2014). Adres do korespondencji: Instytut Pedagogiki KUL (p. DMM III - 125), ul. Droga Męczenników Majdanka 70, 20-325 Lublin. Adres e-mail: sztabowy@gmail.com. 